\title{
Degarelix/Enzalutamide Regimen
}

National Cancer Institute

\section{Source}

National Cancer Institute. Degarelix/Enzalutamide Regimen. NCI Thesaurus. Code

C160516.

A regimen consisting of degarelix and enzalutamide that can be used for the treatment of prostate cancer. 